\title{
Choroidal Thickness in Children with Congenital Heart Disease Measured by Spectral Domain Optical Coherence Tomography ${ }^{\S}$
}

\section{Özgün Araştırma Research Article}

Received/Geliş: 13.07 .2020 Accepted/Kabul: 27.09.2020 First Online: 28.09 .2021

Fatoş Alkan

Celal Bayar Üniversitesi Tıp Fakültesi, Pediyatrik Kardiyoloji Bilim Dalı, Manisa, Türkiye fatos.alkan@hotmail.com ORCiD: 0000-0001-5011-707X

S. Şen 0000-0003-2960-1793 Celal Bayar Üniversitesi Tıp Fakültesi, Çocuk Hastalıkları Anabilim Dalı, Manisa, Türkiye

E. Çavdar 0000-0001-7947-0512 Merkez Efendi Devlet Hastanesi, Göz Hastalıkları Kliniği Manisa, Türkiye

ş. Coşkun 0000-0002-8056-082X Celal Bayar Üniversites Tıp Fakültesi, Pediyatrik Kardiyoloji Bilim Dalı, Manisa, Türkiye

${ }^{5}$ Presented as a poster presentation at the 17th National Congress of Pediatric Cardiology and Cardiovascular Surgery (18-21 April, 2018

Cite as: Alkan F, Şen S, Çavdar E, Coşkun Ş. Choroidal thickness in children with congenital heart disease measured by spectral domain heart disease measured by spectral domain
optical coherence tomography. Tepecik Eğit. ve Araşt. Hast. Dergisi. 2021;31(3):338-43.

\section{Doğuştan Kalp Hastalıklı Çocuklarda Optik Koherens Tomografi ile Koroid Kalınlığının Değerlendirilmesi}

\author{
Fatoş Alkan ${ }^{\oplus}$, Semra Şen®, Ercüment Çavdar ${ }^{\oplus}$, Şenol Coşkun ${ }^{\oplus}$
}

\section{ABSTRACT}

Objective: The main reason for complications in congenital heart diseases (CHD) is decreased blood oxygen saturation and polycythemia which are typical for cyanosis. These parameters may promote the damage of the retina because haemodynamic regulation is essential for the structural and functional integrity of the macular subfields. The aim of this study was to evaluate choroidal thickness (CT) measurements in children with CHD using spectral domain optical coherence tomography (OCT).

Methods: This prospective study compared $30 \mathrm{CHD}$ and 30 healthy control children. CT was examined with spectralis spectral-domain OCT (Retinascan RS-3000; Nidek). CT was obtained at the subfovea, $500 \mu \mathrm{m}$ and 1000 $\mu \mathrm{m}$ nasal to the fovea $(\mathrm{N} 500, \mathrm{N1000})$ and $500 \mu \mathrm{m}$ and $1000 \mu \mathrm{m}$ temporal to the fovea (T500, T1000). Only the right eye values were used for statistical comparisons between the groups. The domain cardiac lesions were divided physiologically into two categories: volume overload and cyanotic.

Results: Mean age was $11.0 \pm 3.5$ years in CHD childrens and $10.9 \pm 3.6$ years in the control group ( $p=0.971)$. Children with CHD had no statistically significant CT measurements compared with healthy controls ( $p>0.05$ ).

Conclusion: Although in high haematocrit, low oxygen saturation or the presence of the volume overload in the history of CHD patients, our data suggests that patients with CHD show normal CT. The reason may be medical and surgical treatment of hypoxia, erythrocytosis and volume overload in CHD patients.

Keywords: Congenital heart disease, choroidal thickness, optical coherence tomography, polycythemia, cyanosis

Öz

Amaç: Spektral-domain optik koherens tomografi (SDOKT) kullanarak doğuştan kalp hastalıklı (DKH) çocuklarda koroid kalınlığının değerlendirilmesi amaçlanmıştır. Doğuştan kalp hastalığında komplikasyonların başlıca nedeni, siyanoz için tipik olan düşük arteriyel oksijen saturasyonu ve polisitemidir. Bu parametreler retinal hasarı artırabilir, çünkü hemodinamik regülasyon makuler alt alanların yapısal ve işlevsel bütünlüğü için gereklidir.

Yöntem: Bu prospektif çalıșmada 30 DKH'lı ve 30 sağlıklı çocuk karşılaştırıldı. Koroid kalınlığı SDOKT ile incelendi (Retinascan RS-3000; Nidek). Koroidal kalınlık; subfovea, $500 \mu \mathrm{m}$ ve $1000 \mu \mathrm{m}$ nazal fovea (N500, N1000) ve $500 \mu \mathrm{m}$ ve 1000 um temporal foveal alan (T500, T1000) ölçülerek elde edildi. Gruplar arasındaki istatistiksel karşılaștırmalar için sadece sağ göz değerleri kullanıldı. Kardiyak patolojiler fizyolojik olarak volüm yükü yapan ve siyanotik olarak iki kategoriye ayrildı.

Bulgular: DKH'li çocuklarda yaş ortalaması $11.0 \pm 3.5$ yıl, kontrol grubunda 10.9 \pm 3.6 yıl idi $(p=0.971)$. DKH'li çocuklar, sağlıklı kontrollerle karşılaştırıldığında istatistiksel olarak anlamlı koroidal kalınlık ölçümleri saptanmadı $(p>0.05)$.

Sonuç: DKH çocuklar da yüksek hematokrit, düşük arteriyel oksijen saturasyonu veya aşırı volüm yükü nedeniyle olası retinal vasküler değişikler beklenmesine karşın, çalışmamızda DKH'ı hastaların normal koroidal kalınlık gösterdiklerini saptadık. Bu durum hastalarımızın çoğunda uygulanmış medikal yada cerrahi tedavi ile retinal vasküler değişiklerin iyileștirilmesine bağlı olabilir.

Anahtar kelimeler: Doğuștan kalp hastalığı, koroid kalınlığı, optik koherens tomografi, polisitemi, siyanoz
(C) Telif hakkı T.C. Sağıık Bakanlı̆ı̆ı İzmir Tepecik Eğit. ve Araşt. Hastanesi. Logos Tıp Yayıncılık tarafindan yayınlanmaktadır. Bu dergide yayınlanan bütün makaleler Creative Commons Atff-GayriTicari 4.0 Uluslararası Lisansı ile lisanslanmıștır.

(c) Copyright Association of Publication of the T.C. Ministry of Health İzmir Tepecik Education and Research Hospital. This journal published by Logos Medical Publishing. Licenced by Creative Commons Attribution-NonCommercial 4.0 International (CC BY-NC 4.0) 


\section{INTRODUCTION}

Congenital heart disease (CHD), especially cyanotic heart diseases, is a complex group with high morbidity and mortality. Advances in invasive and surgical procedures and clinical treatment applied and the life expectancy of these patients have improved significantly. There are anecdotal reports of an increased frequency of ocular pathologies in congenital heart diseases ${ }^{(1)}$. The vascular system of the eye is exposed to the same internal and environmental effects, except for some features, and many features of the heart with the vascular system are similar ${ }^{(2)}$. The CHD patients may have vascular abnormalities such as arterial and venous occlusive disease, increased retinal vascular tortuosity, retinal arteriolar aneurysm, and embolic events. This may be due to chronic hypoxia, polycythemia and vascular changes especially in cyanotic CHD patients. This situation is parallel with the improvement of retinal vascular patterns with the improvement of hypoxia and erythrocytosis after surgery. Spectral-domain OCT enables noninvasive visualization and measurement of retinal and choroidal layers. We aimed to evaluate the $\mathrm{CT}$ in children with CHD measured by OCT.

\section{MATERIALS and METHODS}

A cohort study among 30 CHD (22 male, 8 female) and 30 healthy children ( 22 male, 8 female) was conducted in Celal Bayar University, Department of Pediatric Cardiology, Turkey between January 2016 and January 2017. Ethics committee approval was obtained by the local ethics committee (14.10.2015, 20478486-362), and written consent was obtained from parents.

The participants were devided into two groups: patients with CHD and the control group with healthy children. Congenital heart disorders are classified into two categories, cyanotic and acyanotic. In the acyanotic category included lesions that cause volume load with increased pulmonary blood flow (ventricular septum defect, atrial septal defect, patent ductus arteriosus, atrio-ventricular septal defect). In the cyanotic category, there were lesions with decreased pulmonary blood flow (tetralogy of fallot, pulmonary atresia, tricuspid atresia, ebstein anomaly) or increased pulmonary blood flow (large artery transposition, truncus arteriosus, double outlet right ventricle, total pulmonary venous return anomaly). The CHD patients were compared with 30 healthy children (control group) who were admitted to the pediatric cardiology department with nonspecific symptoms such as murmur, chest pain and dizziness, who were matched in terms of age and gender and whose cardiac evaluations were found to be negative. Systolic and diastolic blood pressures were measured. The CHD group was evaluated for hematocrit and hypoxia.

Participants with a history of ocular disorders, such as any type of glaucoma, previous ocular surgery or injury, and participants with a history of any systemic disease that could affect the choroidal circulation, such as hypertension, diabetes, vasculitis or kidney failure, were excluded from the study. Each participant underwent a complete ocular examination. CT was examined with spectral domain OCT (Retinascan RS-3000; NIDEK, Gamagori, Japan).

Spectral domain OCT is a new radiation-free imaging technique that can provide cross-sectional views of retinal anatomy. With the aid of near infrared 840 $\mathrm{nm}$ diode laser light, OCT uses the optically reflective properties of tissues to provide detailed information about inner retinal structures. CT of the right eyes were examined. Macula Line Raster scan protocol was used to evaluate the subfoveal CT, which enables good-quality depth penetration with 120 averaged B-scans ${ }^{(3,4)}$. CT was measured perpendicularly from Bruch's membrane equivalent to the choroid-sclera interface at the fovea and at 4 more points located at $500 \mu \mathrm{m}$ nasal to the fovea, $1000 \mu \mathrm{m}$ nasal to the fovea, $500 \mu \mathrm{m}$ temporal to the fovea and $1000 \mu \mathrm{m}$ temporal to the fovea drawn by one experienced examiner who was blinded to the diagnosis of the participants ${ }^{(3,4)}$. SD-OCT measurements of all patients were taken between 10:00 and 11:00 AM and three 
images were taken from each participant, and the one with the highest signal strength was used for analysis.

\section{Statistical Analysis}

All data was documented into Statistical Package for Social Sciences (SPSS) on Windows 15.0. Data was expressed as mean and standard deviation. Independent $\mathrm{T}$ test was performed in independent groups for normal distribution parameters. Mann Whitney $U$ test was performed not showing normal distribution in independent group. A p value $<0.05$ was considered statistically significant.

\section{RESULTS}

This study included 30 eyes with $30 \mathrm{CHD}$ and 30 healthy eyes. Mean age was $11 \pm 3.51$ years (range,
5-17 years) in CHD children and $10.9 \pm 3.6$ years (range, $5-18$ years) in the control group. No significant difference was found between the groups in terms of gender or age. There was no statistically significant difference in the SBP and DBP values between the groups. The clinical characteristics of the CHD and control group participants are shown in (Table 1). Physiologic cardiac categories included two groups: volume overload in $18(60 \%)$, cyanotic in $12(40 \%)$. The most common anatomic cardiac anomalies were ventricular or atrial septal defects $15(50 \%)$, followed by tetralogy of Fallot $8(26,6 \%)$. Other lesions were transposition of the great arteries 1 (3,3\%), doubleoutlet right ventricle $2(6,6 \%)$, atrio-ventricular canal $3(10 \%)$ and ebstein anomaly $1(3,3 \%)$ (Table 2$)$. Two participants with atrio-ventricular septal defect were Down syndrome. There was no correlation between the anatomic types of CHD and CT.

Table 1. Baseline characteristics of the congenital heart disease and control groups.

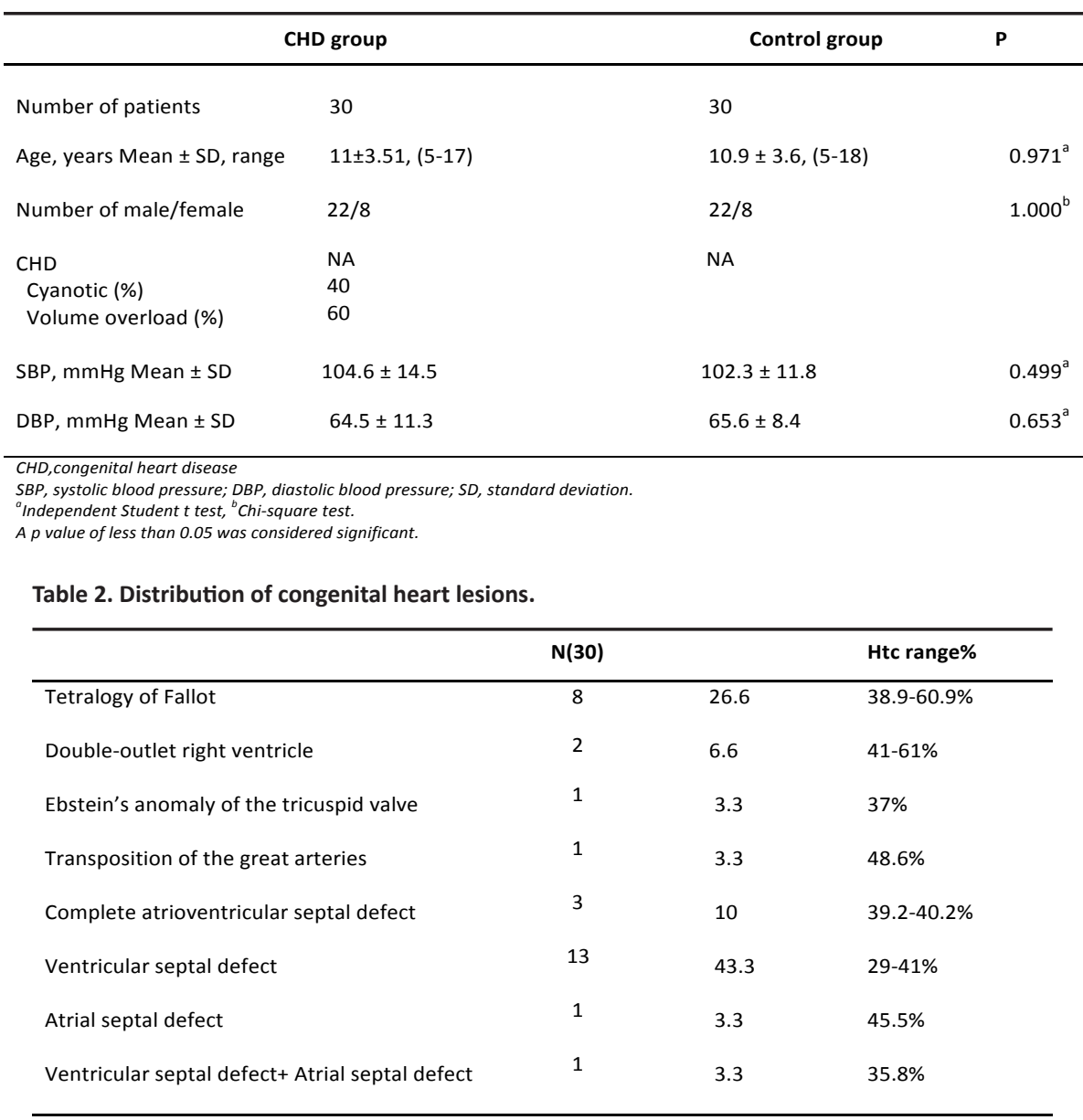


Table 3. Foveal thickness and choroidal thickness measurments.

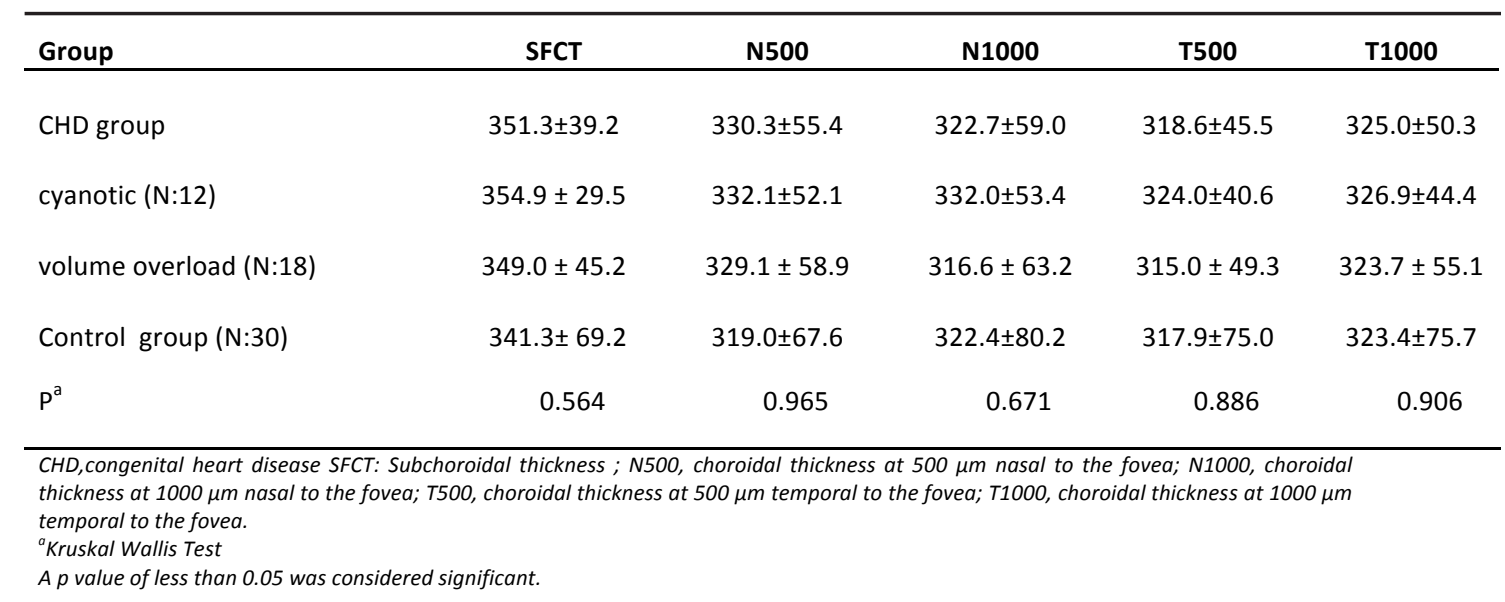

$27 \%$ of patients with volume overload were operated $(n=5)$ and $61 \%(n=11)$ of them were receiving medical treatment. $66 \%{ }^{(8)}$ of the patients in the cyanotic group were operated, and only $33 \%{ }^{(4)}$ of the patients in this group had continued cyanosis.

A total of 13 (43\%) participants had undergone some type of surgical intervention prior to the eye examination. In cyanotic group, the hematocrit level of 2 patients was above $55 \%$ and only 4 patients in this group had continued cyanosis. There was no correlation between CT, level of haematocrit and low arterial oxygen saturation. There was no significant difference between $\mathrm{CT}$ with cyanotic, volume overload and control participants in the subfovea, $\mathrm{N} 500 \mu \mathrm{m}, \mathrm{N} 1000 \mu \mathrm{m}$ nasal to the fovea and T500 $\mu \mathrm{m}, \mathrm{T} 1000 \mu \mathrm{m}$ temporal to the fovea. Table III shows the results of the between-group comparison of SFCT, N500, N1000, T500, T1000.

\section{DISCUSSION}

In the past few decades, advancing surgical techniques and advances in cardiopulmonary bypass surgery, intensive care, cardiac catheterization, noninvasive imaging, and medical treatments have significantly reduced mortality rates for children and adolescents with complex CHD ${ }^{(5-7)}$. As a result of improved survival rates, the target of clinical research in pediatric cardiology has shifted from short-term surgical survival to assessment of long-term morbidity (7). Children under the age of 15 years old with primary CHD have a high prevalence of ocular alterations, with external ocular and retinal manifestations, with higher occurrence rate among cyanotic cases ${ }^{(8)}$. K. Schuster et al. ${ }^{(9)}$ found evidence of a correlation between subfoveal choroidal thickness and cardiovascular risk factors which was mediated by aging. These studies are often in adults and are associated with structural eye diseases $(8,9)$. There are very few studies evaluating direct choroid in congenital heart disease, especially in children. In cyanotic CHD, arterial hypoxemia occurs when unsaturated blood distribution into the systemic circulation due to intracardiac right-to-left shunt (10-12). The cyanotic CHD patients had significant thinning of the central macula and macular subfields ${ }^{(12)}$.These findings may be due to the effect of low oxygen levels due to hemodynamic irregularity, which affects the structural and functional integrity of the retina ${ }^{(13-15)}$. Therefore, there may be structural changes in the retina due to systemic hemodynamic changes in CHD patients ${ }^{(16)}$. Vascular changes caused by chronic hypoxia severely affect whole body and blood parameters, and cardiaceffects of reoxygenation after chronic hypoxia may be more severe than in acute hypoxia (17). Petersen et al. (18) found that hypoxia and polycythemia were associated with dilatation and tortuosity of retinal vessels in about half of patients with cyanotic CHD. Mansour et al. ${ }^{(19)}$ 
suggested that patients with high or low haematocrit develop retinal tortuosity. In patients with normal haematocrit, low oxygen saturation orvelocardiofacial syndrome may be responsible for tortuosity. Retinal arteriolar tortuosity has been reported previously in approximately half of patients with aortic coarctation, and more recently these patients were found not to exhibit these findings due to early surgical correction of the cardiac lesion, suggesting the hemodynamic etiology of vascular tortuosity ${ }^{(16,19)}$. Similarly, previous studies have shown that retinal vascular dilatation and tortuosity in patients with cyanotic CHD are reduced after surgical correction and appear to be associated with a combination of polycythemia and hypoxia ${ }^{(19-21)}$. Chronic ischemia caused by hypoxia in particularly patients with cyanotic CHD occurring secondary to this may be the reason for low subfoveal choroidal thickness. Thin choroidal layer may lead to the development of retinal diseases such as maculopathy, macular degeneration ${ }^{(12)}$.

Our patients also had early surgery and medical treatment to control hypoxia and polycythemia before the eye exam. Therefore, we didn't find any statistically significant difference in choroidal thickness of CHD and age- and gender-matched healthy controls. This may confirm other authors' hypothesis ${ }^{(15,20,21)}$.

In conclusion, It has been reported that choroidal thickness decreases according to the degree of polycythemia and hypoxia, especially in cyanotic CHD ${ }^{(10)}$. Improvement of hypoxia and polycythemia in cardiac lesions with early surgical correction and medical treatment may make retinal changes reversible. For this reason, we didn't find any difference between choroidal thickness of CHD group compared to the control group in our study. In order to reach a more definitive conclusion, studies with larger groups and longer follow-up periods are needed, especially before and after the operation.

Ethics Committee Approval: Celal Bayar University Ethics Committee approval was received (14.10.2015, 20478486-362).
Conflict of Interest: None.

Funding: None.

Informed Consent: Informed consent was obtained

\section{REFERENCES}

1. Vilela MA, Sbruzzi G, Pellanda LC. Prevalence of ophthalmological abnormalities in children and adolescents with CHD: Systematic review and meta-analysis of observational studies. Cardiol Young 2016;26:477-84. [CrossRef]

2. Flammer J, Konieczka K, Bruno RM, Virdis A, Flammer AJ, Taddei S. The eye and the heart. Eur Heart J 2013;34:1270-8. [CrossRef]

3. Spaide RF, Koizumi H, Pozzoni MC. Enhanced depth imaging spectral-domain optical coherence tomography. Am J opthalmol 2008;146:496-500. [CrossRef]

4. Margolis R, Spaide RF. A pilot study of enhanced depth imaging optical coherence tomography of the choroid in normal eyes. Am J Ophthalmol. 2009;147(5):811-5. [CrossRef]

5. Mahle WT, Spray TL, Wernovsky G, Gaynor JW, Clark BJ 3rd. Survival after reconstructive surgery for hypoplastic left heart syndrome: a 15-year experience from a single institution. Circulation 2000;102:136-41. [CrossRef]

6. Jacobs JP, Quintessenza JA, Burke RP, et al. Analysis of regional congenital cardiac surgical outcomes in Florida using the Society of Thoracic Surgeons Congenital Heart Surgery Database. Cardiol Young 2009;19:360-9. [CrossRef]

7. Marino BS, Lipkin PH, Newburger JW, et al; American Heart Association Congenital Heart Defects Committee, Council on Cardiovascular Disease in the Young, Council on Cardiovascular Nursing, and Stroke Council. Neurodevelopmental outcomes in children with congenital heart disease: evaluation and management: a scientific statement from the American Heart Association. Circulation 2012;126:1143-72. [CrossRef]

8. Vilela MA, Colossi CG, Freitas HP, Valle GD, Pellanda LC. Ocular Alterations Associated with Primary Congenital Heart Disease - A Cross-sectional Study. Middle East Afr J Ophthalmol. 2020;27(1):28-33. [CrossRef]

9. Schuster AK, Leuschner A, Feretos C, et al. Choroidal thickness is associated with cardiovascular risk factors and cardiac health: the Gutenberg Health Study. Clin Res Cardiol. 2020;109(2):172-182. [CrossRef]

10. Friedman AH, Fahey JT. The transition from fetal to neonatal circulation: normal responses and implications for infants with heart disease. Semin Perinatol 1993;17:106-21.

11. Rudolph AM. The changes in the circulation after birth. Their importance in congenital heart disease. Circulation 1970; 41: 343-359. [CrossRef]

12. De Aguiar Remigio MC, Brandt CT, Santos CCL, Arantes TE, de Aguiar MIR. Macular and peripapillary retinal nerve fibre layer thickness in patients with cyanotic congenital heart disease. Eye 2015; 29:465-468. [CrossRef]

13. Flammer J, Mozaffarieh M. Autoregulation, a balancing act between supply and demand. Can J Ophthalmol 2008;43:31721. [CrossRef]

14. Neufeld AH, Kawai SI, Das S, et al. Loss of retinal ganglion cells following retinal ischemia: the role of inducible nitric oxide synthase. Exp Eye Res 2002;75:521-528. [CrossRef]

15. Caprara C, Grimm C. From oxygen to erythropoietin: 
relevance of hypoxia for retinal development, health and disease. Prog Retin Eye Res 2012; 31: 89-119. [CrossRef]

16. Johns KJ, Johns JA, Feman SS. Retinal vascular abnormalities in patients with coarctation of the aorta. Arch Ophthalmol 1991;109:1266-8. [CrossRef]

17. Corno AF, Milano G, Samaja M, Tozzi P, von Segesser LK. Chronic hypoxia: A model for cyanotic congenital heart defects, The Journal of Thoracic and Cardiovascular Surgery 2002;124:105-12. [CrossRef]

18. Petersen RA, Rosenthal A. Retinopathy and papilledema in cyanotic heart disease. Pediatrics 1972;49:243-9.

19. Mansour AM, Bitar FF, Traboulsi El, et al. Ocular pathology in congenital heart disease. Eye (Lond) 2005; 19:29-34. [CrossRef]

20. Crowe RJ, Kohner EM, Owen SJ, Robinson DM. The retinal vessels in congenital heart disease. Med Biol 1969;19: 95-9.

21. Kohner EM, Allen EM, Saunders KB, Emery VM, Pallis C. Electroencephalogram and retinal vessels in congenital cyanotic heart disease before and after surgery. Br Med J 1967; 4:207-10. [CrossRef] 